\title{
PENINGKATAN KEMAMPUAN MEMBACA INTENSIF DENGAN MENGGUNAKAN METODE SQ4R( Survey, Read, Review, Recite, Reflect ) DI KELAS VIII SMP. GUPPI SAMATA GOWA
}

\author{
Aliem Bahri ${ }^{1}$ Mila Karmila ${ }^{2}$ \\ Fakultas Keguruan dan Ilmu Pendidikan, Universitas Muhammadiyah Makassar \\ aliem.b@gmail.com \\ Fakultas Keguruan dan Ilmu Pendidikan, Universitas Muhammadiyah Makassar \\ mhylacuten@gmail.com
}

\begin{abstract}
This research was a classroom action research (PTK) with the presentation of data and descriptions kuantitatif. Qualitative research descriptions was conducted in two cycles. Each cycle consists of four phases: planning, action, observation, and reflection. Data learning process of each cycle were analyzed descriptively qualitative. The data were analyzed descriptively learning outcomes kuantitatif. Subjek this research is class VIII totaling 16 orang.Tindakan given is intended to determine the increase in the learning process and learning outcomes in cycle I. As for the second cycle in the form of corrective actions against deficiencies experienced in cycle I. Results of the data analysis of the results of the study in the first cycle and the second cycle is concluded that, teaching intensive reading in class VIII SMP-I Guppi Samata Gowa by using SQ4R method can improve the learning process and learning outcomes intensive reading. Conclusions based on these results, the researchers suggested to the teachers to always use the methods that can stimulate students' attention so that the students were interested in learning. For other researchers and students who pursue teaching Indonesian language and literature are expected to conduct research in the areas of reading by using other methods, as well as in intensive reading so it can be found a variety of learning methods that can be used as learning in school.
\end{abstract}

Keywords: Intensive Reading, Methods SQ4R

\begin{abstract}
Abstrak
Penelitian ini bersifat penelitian tindakan kelas (PTK) dengan pemaparan data deskripsi kualitatif dan deskripsi kuantitatif.Penelitian ini dilaksanakan dalam dua siklus. Setiap siklus terdiri atas 4 tahap yaitu: tahap perencanaan, pelaksanaan tindakan, observasi, dan refleksi. Data proses pembelajaran setiap siklus dianalisis secara deskriptif kualitatif. Adapun data hasil pembelajaran dianalisis secara deskriptif kuantitatif.Subjek penelitian ini adalah siswa kelas VIII yang berjumlah 16 orang.Tindakan yang diberikan dimaksudkan untuk mengetahui peningkatan proses pembelajaran dan hasil pembelajaran pada siklus I. Adapun siklus II berupa tindakan perbaikan terhadap kekurangan-kekurangan yang dialami pada siklus I.

Hasil analisis data yang dilakukan terhadap hasil penelitian pada siklus I dan siklus II disimpulkan bahwa, pembelajaran membaca intensif pada siswa kelas VIII-I SMP Guppi Samata Gowa dengan menggunkan metode SQ4R dapat meningkatkan kemampuan pada proses pembelajaran dan hasil pembelajaran membaca intensif. Berdasarkan simpulan hasil penelitian ini, peneliti menyarankan kepada guru agar senantiasa menggunakan metode yang dapat merangsang perhatian siswa sehingga siswa merasa tertarik untuk belajar. Bagi peneliti lain dan mahasiwa yang menekuni pengajaran bahasa dan sastra Indonesia diharapkan melakukan penelitian dalam bidang membaca dengan menggunakan metode lain, demikian pula dalam membaca intensif sehingga dapat ditemukan berbagai metode pembelajaran yang dapat digunakan sebagai pembelajaran di sekolah.
\end{abstract}


Kata Kunci: Membaca Intensif, Metode SQ4R

\section{PENDAHULUAN}

Pembelajaran bahasa Indonesia secara fungsional adalah pembelajaran yang lebih menekankan siswa untuk belajar berbahasa dalam kaitannya dengan fungsi bahasa sebagai alat untuk berkomunikasi. Dalam pembelajaran bahasa indonesia, membaca merupakan salah satu keterampilan berbahasa yang diajarkan. Tujuan pembelajaran membaca di sekolah adalah membina siswa agar mereka memiliki kemampuan dan keterampilan yang baik dalam membaca. Siswa diharapkam mampu menangkap ide, gagasan, dan pendapat dengan baik dan benar serta memiliki pengetahuan lebih saat proses membaca itu dilakukan.

Membaca pada dasarnya merupakan suatu aktivitas yang dapat dilakukan oleh siapa pun, di mana pun, dan kapan pun serta dengan objek yang sangat beraneka ragam. Tujuan melakukan aktivitas ini sangat bervariatif, meskipun bisa dikatakan umumnya dilakukan untuk memperoleh pengetahuan sebanyak-sebanyaknya di samping untuk mencari hiburan semata.

Kegiatan membaca pada dasarnya dimulai dari tindakan konseptual, yakni aktivitas yang mengenal kata sampai pada makna berdasarkan pengalaman yang lalu. Kegiatan persepsi melibatkan pesan dan kesan sensoris yang masuk ke otak. Ketika seorang melakukan aktivitas membaca, otak menerima gambaran kata-kata kemudian mengungkapkan dari halaman cetak berdasarkan pengalaman pembaca sebelumnya dengan objek, gagasan, atau emosinya.

Anak-anak yang mengetahui pentingnya membaca akan membiasakan dirinya membaca. Membaca akan lebih mudah dilakukan apabila diketahui bagaimana melakukannya. Dalam membaca dikenal salah satu cara yaitu membaca intensif. Membaca intensif adalah membaca dengan menemukan detail atau perincian isi bacaan. Dalam membaca intensif diperlukan konsentrasi untuk membaca teks bacaan secara mendalam.

Membaca intensif merupakan kompetensi dasar yang terdapat dalam kurikulum tingkat satuan pendidikan (KTSP). Membaca akan lebih bermanfaat jika disertai dengan diskusi (sebelum, selama, dansesudah membaca). Keterampilan dalam membaca sering terhambat karena guru kurang tepat dalam menerapkan metode yang digunakan dalam proses pembelajaran sehingga berdampak pada kurangnya motivasi, minat, dan partisipasi (pembiasaan) siswa untuk membaca.

Keberhasilan pengajaran membaca menjadi salah satu tanggung jawab guru (Guru bahasa Indonesia). Guru sebagai perencana, pengelola, fasilitas, dan motivator senantiasa berusaha untuk berkreasi dan berinovasi dalam meningkatkan minat dan kemampuan membaca siswanya.

Pembelajaran membaca pada dasarnya dapat dilakukan dengan berbagai metode atau strategi. Namun, untuk mengatasi kondisi sepertiitu peneliti menawarkan satu solusi dalam permasalahan membaca. Adapun solusi yang ditawarkam adalah penggunaan metode SQ4R (Survey,Question,Read, Review, Recite dan Reflect).SQ4Radalah pengembangan dari metode SQ3R. Sasaran utama pembelajaran membaca dengan metode SQ4R adalah belajar atas kemauan sendiri dan meningkatkan upaya pelajar memahami teks yang dibaca dalam jangka yang lebih singkat. Dengan kata lain, pengajaran membaca dengan metode SQ4R adalah untuk membentuk siswa sebagai 
pelajar yang mandiri (self regulation learner).

Metode SQ4R merupakan pengembangan dari metode SQ3R.metode ini pada dasarnya membentuk siswa untuk dapat meningkatkan proses belajar dengan memahami teks yang akan dibaca dalam jangka waktu yang lebih singkat.

Menurut Nuriadi ( 2008: 178) model SQ4R ini merupakan sebuah sistem yang diterapkan dalam melakukan aktivitas membaca dan/atau belajar berupa observasi (Survey), bertanya (Question), membaca (Read) menyatakan kembali (Recite), mengulang (Review), dan refleksi (Mengamati) - SQ4R. dikatakan sebuah sistem karena model ini merupakan sebuah mata rantai yang setiap bagiannya saling berkaitan satu dengan yang lain sehingga harus di lalui oleh pembaca apabila hendak memperoleh pemahaman yang maksimal

\section{METODE PENELITIAN}

\section{A. Pendekatan dan Jenis Penelitian}

Penelitian ini digolongkan ke dalam penelitian tindakan kelas (Classroom Action Reserch). Penelitian ini dilakukan untuk menggambarkan dan mengamati proses belajar siswa kelas VIII SMP Guppi Samata Gowa dengan menggunakan motode SQ4R (Survey, Question, Read, Review, Recite, Reflec). Mekanisme pelaksanaannya dengan bersiklus , setiap siklus masing-masing dilaksanakan dengan empat tahap, yaitu: (1) Perencanaan, (2) Tindakan, (3) Observasi, dan (4) Refleksi. Proses penelitian tindakan kelas ini menggunakan model Kemmis dan Mc. Taggart. model pelaksanaannya dapat digambarkan dalam bentuk spiral tindakan (adaptasi Hopkins yang dikutip oleh Aqip, 2006:31) sebagai berikut:

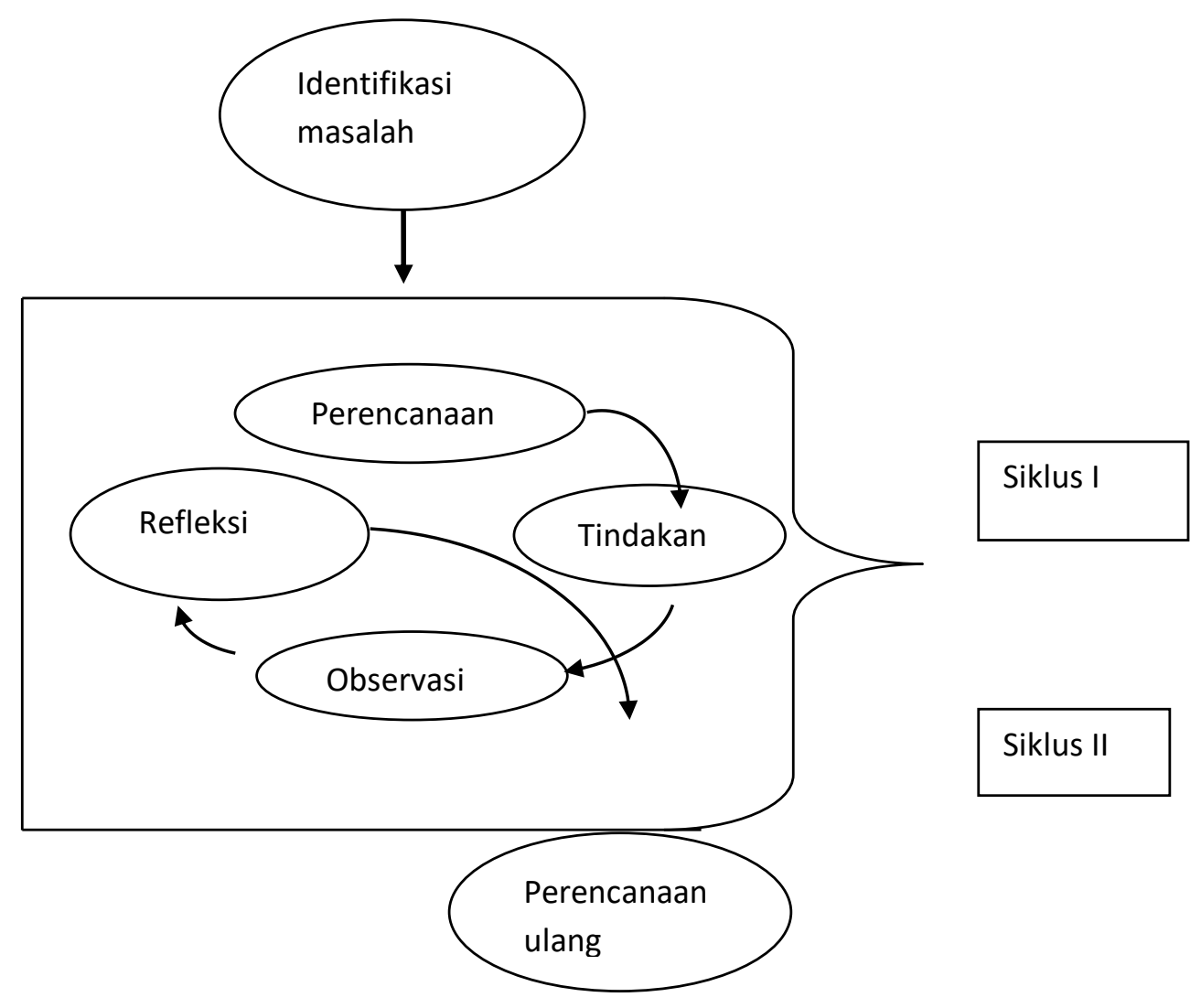




\section{B. Lokasi dan Subjek Penelitian}

Penelitian ini adalah penelitian tindakan kelas yang dilaksanakan di kelas VIII di SMP Guppi Samata Gowa.Penelitian adalah siswa kelas VIII, yang jumlahnya 20 orang yang terdiri dari 11 laki-laki dan 9 perempuan.

\section{Faktor yang Diselidiki}

Untuk menjawab pertanyaan permasalaha penelitian, maka ada beberapa faktor yang diselidiki, yaitu :

1. Faktor siswa, yaitu melihat peningkatan hasil belajar, keaktifan siswa dalam proses belajar mengajar, mengerjakan tugas dari guru baik tugas di Sekolah maupun tugas rumah dan siswa yang aktif dan pasif di dalam kelas.

2. Hasil belajar siswa, guru menilai hasil belajar siswa dan memberikan tes.

\section{Instrumen Penilaian}

Dalam penelitian ini, instrumen yang digunakan adalah :

1. Tes akhir adalah tes yang diberikan pada siswa yang diadakan tiap siklus.

2. Pedoman observasi, yaitu beberapa catatan tentang bagaimana aktivitas siswa dalam proses belajar mengajar.

\section{E. Data dan Sumber Data}

\section{Data Penelitian}

Adapun data dalam
penelitian ini berupa data
perencanaan, data pelaksanaan, data
evaluasi, dan data hasil. Data
penelitian ini diperoleh melalui
observasi, studi dokumentasi, dan
tes dari setiap tindakan perbaikan

penggunaan metode SQ4R dalam pembelajaran membaca intensif bagi siswa kelas VIII SMPGuppi Samata Gowa.

\section{Sumber Data}

Sumber data penelitian ini ada 2 yaitu sumber data lisan dan tertulis. Sumber data lisan adalah informan yang memiliki pengetahuan tentang cara kerja siswa dalam hal ini guru. Sedangkan, sumber data tertulis adalah hasil kerja siswa kelas VIII yang berjumlah 16orang.

\section{F. Teknik Pengumpulan Data}

Teknik pengumpulan data adalah cara yang dilakukan dalam mengumpulkan data yang berhubungan dengan penelitian ini. Namun, dalam penelitian ini peneliti hanya memilih empat dari beberapa teknik yaitu: (1) Teknik wawancara, (2) teknik observasi, (3) teknik dokumentasi, dan (4) teknik tes.

\section{G. Teknik Analisis Data}

Data pada penelitian ini adalah data hasil kemampuan membaca dengan penggunaan metode SQ4R (Survey, Question, Read, Review, Recite, Reflect) siswa serta data yang diperoleh dari hasil observasi dan catatan lapangan. Tahap analisis itu diuraikan sebagai berikut:

1) Menelaah data

Data yang terkumpul melalui observasi, catatan lapangan, dan studi dokumentasi dengan melakukan transkripsi hasil observasi, penyeleksian, dan pemilihan data. Data dikelompokkan berdasarkan data pada tiap siklus. 
2) Reduksi data

Data keseluruhan yang terkumpul diseleksi dan diidentifikasi berdasarkan kelompoknya dan mengklasifikasikan data sesuai dengan kebutuhan.

3) Menyajikan data

Penyajian data dengan cara mengorganisasikan informasi yang telah direduksi. Keseluruhan data dirangkum dan disajikan secara terpadu sesuai siklus yang direncankan sehingga fokus pada pembelajaran

4) Menyimpulkan hasil penelitian

Akhir temuan penelitian disimpulkan dan dilakukan kegiatan tringulasi data atau pengujian temuan penelitian.

Penilaian dilakukan dengan rumus:

\section{Nilai perolehan siswa}

$=\frac{\text { skorperolehan }}{\text { skormaksimum }(100)} \mathrm{X}$ skor ideal (100)

\section{HASIL PENELITIAN}

Permasalahan utama penelitian ini adalah untuk meningkatkan kemampuan pada proses dan hasil pembelajaran membaca intensif dengan menggunakan metode SQ4R (survey, question, read, recite, review, dan reflect).

1. Deskripsi Hasil Penelitian Data Proses Pembelajaran Membaca Intensif dengan Menggunakan Metode SQ4R

\section{a. Siklus I}

Siklus I dilaksanakan berdasarkan rencana pelaksanaan pembelajaran yang telah dibuat oleh peneliti bersama dengan guru.

\section{1) Perencanaan Pembelajaran}

Langkah-langkahnya sebagai berikut ini.

(a) Setiap Siswa menerima bahan bacaan secara tertutup

(b) Siswa melakukan penjajakan dengan membaca sekilas bacaan (judul dan subjudul)

(c) Siswa menyusun pertanyaan mengenai berbagai informasi yang terdapat dalam bahan bacaan

(d) Siswa membaca secara intensif untuk menjawab jawaban atas pertanyaan yang tersaji

(e) Siswa membahas pertanyaan

(f) Siswa menjawab pertanyaan yang telah disususn

(g) Siswa menceritakan isi bacaan

(h) Siswa meninjau kembali isi bacaan

2) Pelaksanaan Tindakan dan Pengamatan Pembelajaran

Pada tahap ini, guru melaksanakan pembelajaran berdasarkan rencana pelaksanaan pembelajaran yang telah dibuat sedangkan peneliti mengamati proses pembelajaran membaca intensif dengan menggunakan metode SQ4R sebagai sumber data kualitatif berdasarkan hasil observasi.

\section{3). Refleksi Pembelajaran}


Kegiatan refleksi dilakukan secara kolaboratif anatara peneliti dan guru untuk membahas dan menyimpulkan tentang temuan dan hasil peneliti siklus 1 . Berdasarkan data proses siklus 1 diketahui bahwa dalam proses pembelajaran membaca intensif dengan menggunakan metode SQ4R siswa yang berperilaku aktif dan tidak aktif selama proses pembelajaran berlangsung.

\section{b. Siklus II}

Pembelajaran siklus II dilaksanakan berdasarkan rencana pelaksanaan pembelajaran yang telah di buat setelah merefleksi pembelajaran pada siklus I. Pada siklus II dilakukan perbaikan-perbaikan terhadap kendala yang dihadapi pada siklus I dan memepertahankan pencapaian pada siklus I sebagai upaya untuk meningkatkan hasil pada proses pembelajaran selanjutnya.

\section{Deskripsi Data Penelitian hasil Evaluasi Pembelajaran Membaca Intensif dengan menggunakan Metode SQ4R}

Hasil penelitian untuk data hasil pembelajaran berupa tes kemampuan siswa di akhir siklus berupa penilaian terhadap hasil membaca siswa berdasarkan metode SQ4R.Hasil tes tersajikan dalam bentuk deskriptif kuantitatif dengan penyajian data dalam bentuk tabel dan analisis berupa tafsiran terhadap isi bacaan tersebut.

a. Deskripsi Hasil penelitian Data Hasil Evaluasi Pembelajaran Siklus I

Pada siklus I diperoleh data dari 4 aspek penilaian yaitu : (a) menangkap isi wacana baik yang tersurat maupun yang tersirat, yang meliputi: mendata informasi problematik dan informasi yang kontradiktif, (b) Menceritakan kembali isi wacana dengan bahasanya sendiri, (c) Menemukan gagasan utama dari bacaan tersebut; dan Menjawab pertanyaan dengan lengkap.

\section{b. Deskripsi Hasil Evaluasi Pembelajaran Siklus II}

Pada siklus II diperoleh data dari 4 aspek penilaian yaitu : (a) menangkap isi wacana baik yang tersurat maupun yang tersirat, yang meliputi: mendata informasi problematic dan informasi yang kontradiktif, (b) Menceritakan kembali isi wacana dengan bahasanya sendiri, (c) Menemukan gagasan utama dari bacaan tersebut; dan (d) Menjawab pertanyaan dengan lengkap.

Pada tahap evaluasi pembelajaran, hasil yang dapat dikumpulkan oleh peneliti bahwa siswa kelas VIII SMP. Guppi Samata menunjukkan hasil yang kurang memuaskan dimana hasil tes menunjukkan bahwa siswa yang mendapat nilai 70 ke atas sebanyak 3 siswa atau $18,75 \%$. Berdasarkan tingkat interval penguasaan berada pada kategori kurang.

Pada tahap perencanaan di siklus II, peneliti dan guru merumuskan rencana pelaksanaan pembelajaran tetap sama dengan siklus I, hanya pelaksanaan yang dilakukan akan lebih dimaksimalkan pada kekurangankekurangan pada siklus I dan tema bacaan yang dihadirkan diusahakan lebih menarik. Pengumpulan data tetap dilakukan berdasarkan lembar observasi siswa dan kinerja guru.

Pada tahap perencanaan, Hasil observasi aktivitas siswa pada siklus II menunjukkan $86,8 \%$ siswa aktif mengikuti pembelajaran, hal ini menunjukkan terjadinya peningkatan efektifitas pada pembelajaran yang signifikan yaitu sebesar $30,58 \%$ yang pada sipklus 1 hanya $56,27 \%$. keaktifan siswa sejalan dengan pelaksanaan kinerja guru yang sudah maksimal. 
Secara umum frekuensi siswa yang membaca intensif berdasarkan 4 kriteria penilaian mengalami peningkatan yang2. menunjukkan adanya peningkatan hasil pembelajaran sebagai dampak dari proses pembelajaran yang maksimal.

Pada tahap evaluasi di siklus II, hasil yang dapat dikumpulkan oleh peneliti bahwa siswa kelas VIII SMP.Guppi Samata menunjukkan hasil yang sangat baik dalam membaca. Hasil tes siswa yang telah dievaluasi guru dan peneliti menunjukkan kemajuan yang menggembirakan bagi proses pengajaran membaca intensif dengan3. menerapkan metode SQ4R pada siswa kelas VIII SMP. Guppi Samata.

Dengan hasil yang diperoleh peneliti bahwa hasil penilaian berdasarkan interval nilai yang ditetapkan menunjukkan pada siklus II $86,85 \%$ dari target $\geq 75 \%$ siswa memperoleh nilai 70 ke atas, ini berarti terjadi peningkatan hasil belajar sebagai dampak dari peningkatan proses pembelajaran, sehingga pembelajaran Membaca Intensif dengan menggunakan Metode SQ4R di kelas VIII SMP. Guppi Samata dinyatakan berhasil.

\section{SIMPULAN}

Berdasarkan uraian hasil analisis data dan pembahasan, maka penelitian ini dapat disimpulkan sebagai berikut:

1. Perencanaan keterampilan membaca bahasa Indonesia dengan menerapakan metode SQ4R (Survey, Question, Read, Review, Recite, Reflect) siswa kelas VIII SMP. Guppi Samata Gowa dilakukan dengan membuat Rencana Pelaksanaan Pembelajaran (RPP). Dalam RPP dimuat materi membaca intensif ( siklus I "Ilmuwan Sedari Muda" dan siklus II "Anak yang Tersisih"), langkah-langkah pembelajaran sebagai pendukung keberhasilan Metode SQ4R. Selain langkah- langkah, tercantum pula alat evaluasi keterampilan membaca.

Proses pembelajaran membaca intensif mengalami peningkatan pada saat penggunaan metode SQ4R (Survey, Question, Read, Review, Recite, Reflect). Keaktifan siswa terjadi pada saat proses pembelajaran berlangsung, pada siklus I jumlah siswa yang mengikuti pembelajaran secara aktif sebesar 56,27\%. Pelaksanaan pembelajaran peningkatan keaktifan pada siklus II sebesar $86,85 \%$ siswa aktif mengikuti pembelajaran.

Hasil evaluasi pembelajaran membaca intensif dengan menggunakan metode SQ4R juga menunjukkan peningkatan. Hasil tes membaca siklus I sebesar $53 \%$ siswa memperoleh nilai $65 \mathrm{ke}$ atas dan hasil tes membaca siklus II sebesar $87,5 \%$ siswa memperoleh nilai 65 ke atas.

\section{DAFTAR PUSTAKA}

Aqib, Zainal. 2006. Penelitian Tindakan Kelas bagi Pengembangan Profesi Guru. Bandung: Yrama Widya.

Bahdar, Rinawati. 2008. "Peningkatan Kemampuan Membaca Intensif melalui Pembelajaran Kooperatif Model Penyelidikan Kelompok Siswa Kelas VIII SMP Negeri 26 Makassar". Skripsi (Tidak Diterbitkan) Makassar: FBS UNM.

\section{http://eprints.utm.my/3680/1/71881.pdf}

Kunandar.2008. Langkah Mudah Penelitian Tindakan Kelas sebagai Pengembangan Profesi Guru. Jakarta: Grafindo Persada. 
Lestari, Dwi Endang dkk. 2005. Pelajaran Bahasa dan Sastra Indonesia. Klaten: Intan Pariwara.

Muslich, Masnur. 2007. KTSP :Dasar Pemahaman dan Pengembangan. Jakarta: Bumi Aksara.

Nurgiantoro, Burhan. 1995. Penilaian Pengajaran Bahasa dan Sastra. Yogyakarta: BPEE.

Nurhadi.2007. Membaca Cepat dan Efektif. Bandung: Sinar Baru Algensindo.

Nuriadi. 2008. Teknik Jitu Menjadi Pembaca Terampil. Yogyakarta: Pustaka Pelajar.

Rahiem, Farida. 2008. Pengajaran Membaca di Sekolah Dasar. Jakarta: Bumi Aksara.

Roestiyah. 2008. Strategi Belajar Mengajar. Jakarta: Rineka Cipta.

Suwardi. 2007. Manajemen Pembelajaran: Mencipta Guru Kreatif dan Berkompetensi. Jawa Tengah: Stain Salatiga Press.

Tarigan, Henry Guntur. 2008. Membaca sebagai Suatu Keterampilan Berbahasa. Bandung: Angkasa.

Tim Penyusun Pusat Bahasa. 2005. Kamus Besar Bahasa Indonesia: Edisi ketiga. Jakarta: Balai Pustaka.

Trianto. 2007. Model-Model Pembelajaran Inovatif Berorientasi Kontruktivistik. Jakarta: Prestasi Belajar

Usman, Alimin \& Nurbaya Kaco.Penelitian Tindakan Kelas (Pengantar ke dalam
Pemahaman Konsep dan Aplikasi).

Makassar: UNM. 